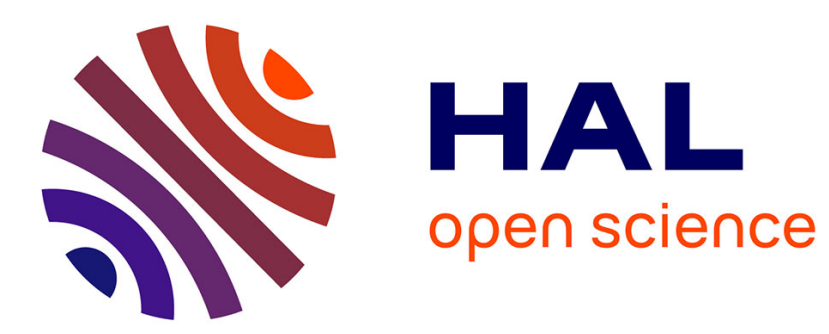

\title{
The beta 2-adrenergic receptor as a surrogate odorant receptor in mouse olfactory sensory neurons
} Masayo Omura, Xavier Grosmaitre, Minghong Ma, Peter Mombaerts

\section{To cite this version:}

Masayo Omura, Xavier Grosmaitre, Minghong Ma, Peter Mombaerts. The beta 2-adrenergic receptor as a surrogate odorant receptor in mouse olfactory sensory neurons. Molecular and Cellular Neuroscience, 2014, 58, pp.1-10. 10.1016/j.mcn.2013.10.010 . hal-01187030

\section{HAL Id: hal-01187030 \\ https://hal.science/hal-01187030}

Submitted on 9 Sep 2015

HAL is a multi-disciplinary open access archive for the deposit and dissemination of scientific research documents, whether they are published or not. The documents may come from teaching and research institutions in France or abroad, or from public or private research centers.
L'archive ouverte pluridisciplinaire HAL, est destinée au dépôt et à la diffusion de documents scientifiques de niveau recherche, publiés ou non, émanant des établissements d'enseignement et de recherche français ou étrangers, des laboratoires publics ou privés. 


\title{
The $\beta 2$-adrenergic receptor as a surrogate odorant receptor in mouse olfactory sensory neurons
}

\author{
Masayo Omura ${ }^{\text {a }}$, Xavier Grosmaitre ${ }^{\mathrm{b}, \mathrm{c}}$, Minghong Ma ${ }^{\mathrm{b}}$, Peter Mombaerts ${ }^{\mathrm{a}, *}$ \\ a Max Planck Research Unit for Neurogenetics, Max-von-Laue-Strasse 3, 60438 Frankfurt, Germany \\ b Department of Neuroscience, University of Pennsylvania School of Medicine, Philadelphia, PA 19104, USA \\ c Centre des Sciences du Goût et de l'Alimentation, 21000 Dijon, France
}

\section{A R T I C L E I N F O}

\section{Article history:}

Received 12 September 2013

Revised 9 October 2013

Accepted 29 October 2013

Available online 6 November 2013

\section{Keywords:}

Main olfactory epithelium

Odorant receptor

B2-adrenergic receptor

G-protein coupled receptor

\begin{abstract}
A B S T R A C T
In the mouse, mature olfactory sensory neurons (OSNs) express one allele of one of the $\sim 1200$ odorant receptor (OR) genes, which encode G-protein coupled receptors (GPCRs). Axons of OSNs that express the same OR coalesce into homogeneous glomeruli at conserved positions in the olfactory bulb. ORs are involved in OR gene choice and OSN axonal wiring, but the mechanisms remain poorly understood. One approach is to substitute an OR genetically with another GPCR, and to determine in which aspects this GPCR can serve as a surrogate OR under experimental conditions. Here, we characterize a novel gene-targeted mouse strain in which the mouse $\beta 2$-adrenergic receptor ( $\beta 2 A R$ ) is coexpressed with tauGFP in OSNs that choose the OR locus $M 71$ for expression $(\beta 2 A R \rightarrow M 71-G F P)$. By crossing these mice with $\beta 2 A R \rightarrow M 71-l a c Z$ gene-targeted mice, we find that differentially tagged $\beta 2 \mathrm{AR} \rightarrow \mathrm{M} 71$ alleles are expressed monoallelically. The OR coding sequence is thus not required for monoallelic expression - the expression of one of the two alleles of a given OR gene in an OSN. We detect strong $\beta 2 \mathrm{AR}$ immunoreactivity in dendritic cilia of $\beta 2 \mathrm{AR} \rightarrow \mathrm{M} 71-\mathrm{GFP}$ OSNs. These OSNs respond to the $\beta 2 \mathrm{AR}$ agonist isoproterenol in a dose-dependent manner. Axons of $\beta 2 A R \rightarrow M 71-G F P$ OSNs coalesce into homogeneous glomeruli, and $\beta 2 A R$ immunoreactivity is detectable within these glomeruli. We do not find evidence for expression of endogenous $32 \mathrm{AR}$ in OSNs of wild-type mice, also not in M71-expressing OSNs, and we do not observe overt differences in the olfactory system of $\beta 2 A R$ and $\beta 1 A R$ knockout mice. Our findings corroborate the experimental value of the $\beta 2 A R$ as a surrogate OR, including for the study of the mechanisms of monoallelic expression.
\end{abstract}

(C) 2013 Elsevier Inc. All rights reserved.

\section{Introduction}

There is still a lack of mechanistic understanding of two fundamental and striking features of mouse olfactory sensory neurons (OSNs). First, each mature OSN expresses one allele of one gene of the 1200 OR genes (Buck and Axel, 1991) that are scattered over more than 40 loci in the genome. The features of monoallelic expression (one of two alleles of an OR gene per OSN) and monogenic expression (one OR gene per OSN) may or may not be governed by the same regulatory mechanisms. Second, axons from OSNs that express the same OR gene coalesce during development into one or a few homogeneous glomeruli in the medial and lateral halves of the olfactory bulb (Mombaerts et al., 1996). These glomeruli reside at conserved positions. The molecular and cellular mechanisms of OR gene choice and OR-specific axonal coalescence into glomeruli remain poorly understood. The models and hypotheses that have been formulated involve the ORs themselves, but it is not clear or has not been addressed to which extent these properties are specific to ORs. Conceivably, ORs may have

\footnotetext{
* Corresponding author at: Max Planck Institute of Biophysics, Max Planck Research Unit for Neurogenetics, Max-von-Laue-Strasse 3, D-60438 Frankfurt, Germany.

E-mail address: peter.mombaerts@biophys.mpg.de (P. Mombaerts).
}

evolved unique functions in certain aspects of OR gene choice and OSN axonal wiring. In other aspects, other GPCRs (non-olfactory GPCRs) may be able to serve as surrogates for ORs under experimental conditions, such as when expressed in an OR-like fashion. Of particular interest are the non-olfactory GPCRs that can couple to $\mathrm{G}_{\alpha}$ olf or $\mathrm{G}_{\alpha}$ s, the $\mathrm{G}$ protein subunits to which ORs couple normally within OSNs. Relatively little is known about structure-function relationships of ORs, but other GPCRs have been characterized extensively because of their pharmacological relevance and ease of heterologous expression. The promise is that the wealth of functional information about well-studied GPCRs such as $\beta 2$ AR (Kobilka, 2013; Lefkowitz, 2013) may then be applied to examine OR functions in OSNs, including their functions in OR gene choice and OSN axonal wiring.

We have shown that the mouse $\beta 2$-adrenergic receptor ( $\beta 2 \mathrm{AR}$ ) can substitute for a mouse OR in several ways (Feinstein et al., 2004). Puzzlingly, another group subsequently reported that $\beta 2 A R$ is expressed endogenously in the main olfactory epithelium (MOE) (Hague et al., 2004), raising the question as to why B2AR expressed from the M71 locus results in axonal coalescence into novel and distinct glomeruli. Transgenic $\beta 2 A R$ expression driven by the MOR23 promoter (Vassalli et al., 2002) also produces distinct glomeruli (Aoki et al., 2013; Nakashima et al., 2013). 
Here, we have generated a novel gene-targeted strain in which mouse $\beta 2 A R$ is expressed together with tauGFP from the $M 71$ locus. In mice of a cross of the two differentially tagged $\beta 2 A R \rightarrow M 71$ alleles, OSNs express either taulacZ or tauGFP but not both, thereby excluding an essential and specific role of the OR coding sequence in monoallelic expression (Nguyen et al., 2007). Patch-clamp recordings reveal that GFP + OSNs respond to the $\beta 2 \mathrm{AR}$ agonist isoproterenol in a dosedependent manner. Despite extensive analyses of $\beta 2 A R$ gene and protein expression, we are not able to confirm the $\beta 2 A R$ expression findings of Hague et al., 2004. Specifically, we do not find evidence of endogenous $\beta 2 \mathrm{AR}$ expression in M71 + OSNs. Moreover, $\beta 2 \mathrm{AR}$ and $\beta 1 A R$ knockout mice have no overt defects in their olfactory system. Nonetheless, with the same in situ hybridization technique we can show that another GPCR gene, the dopamine type-2 receptor (Drd2), is strongly expressed in the MOE across all mature OSNs. Our results corroborate the experimental value of $\beta 2 A R$ as a surrogate OR for studying various aspects of OR gene choice and axonal wiring.

\section{Results}

\section{The $\beta 2 A R \rightarrow M 71$-IRES-tauGFP strain}

We have generated and characterized a mouse strain carrying a $\beta 2 A R \rightarrow M 71-I R E S-t a u l a c Z$ gene-targeted mutation (Feinstein et al., 2004), abbreviated $\beta 2 A R \rightarrow$ M71-lacZ (Fig. 1A). The design of this coding region replacement is such that OSNs that choose the mutant $M 71$ locus for expression do not produce M71 protein but $\beta 2 A R$ instead. In order to enable physiological analysis of $\beta 2 A R \rightarrow M 71$ OSNs, we have now generated another mouse strain with a $\beta 2 A R \rightarrow$ M71-IRES-tauGFP genetargeted mutation, abbreviated $\beta 2 A R \rightarrow M 71-G F P$ (Fig. 1A). The design matches that of the $\beta 2 A R \rightarrow M 71-I R E S-t a u l a c Z$ mutation, except for expression of the marker GFP instead of $\beta$-galactosidase.

The cell bodies of $\beta 2 A R \rightarrow M 71-G F P$ OSNs are scattered within the dorsal MOE (Fig. 1B), as is the case for OSNs expressing M71 (Bozza et al., 2002) or $\beta 2 A R \rightarrow M 71-l a c Z$ (Feinstein et al., 2004). These OSNs display a dendritic knob from which cilia emanate (inset in Fig. 1B). The number of GFP + cells in $\beta 2 \mathrm{AR} \rightarrow \mathrm{M} 71$-GFP homozygous mice aged three weeks is $1262 \pm 132(\mathrm{n}=3)$ per mouse. In situ hybridization (ISH) of the MOE shows that $\beta 2 \mathrm{AR} \rightarrow \mathrm{M} 71$-GFP OSNs are either Omp + Gap43 - (mature), Omp - Gap43 + (immature), or Omp + Gap43 + (intermediate) (Fig. 1C). Quantification of the three stages reveals that, as a population, $\beta 2 \mathrm{AR} \rightarrow \mathrm{M} 71-\mathrm{GFP}$ OSNs are somewhat less mature compared to M71 OSNs (Fig. 1C). In a cross of $\beta 2 A R \rightarrow M 71-G F P \times$ $\beta 2 \mathrm{AR} \rightarrow \mathrm{M} 71$-lacZ mice, immunohistochemistry (IHC) for $\beta$-galactosidase combined with the intrinsic fluorescence of GFP shows that individual OSNs express either marker but not both (Fig. 1D1); we counted 636 GFP + cells and 1162 lacZ + cells, but no lacZ/GFP double-positive cells. Likewise, in a cross of $\beta 2 A R \rightarrow M 71$-lacZ $\times$ M71-IRES-tauGFP mice, OSNs express either marker but not both (Fig. 1D2); we counted 442 lacZ+ cells and 460 GFP + cells, but no lacZ/GFP double-positive cells. Thus, the $\beta 2 A R \rightarrow$ M71-GFP allele is expressed monoallelically: with regard to the differentially tagged $\beta 2 \mathrm{AR} \rightarrow \mathrm{M} 71$-lacZ allele, and with regard to the tagged M71 allele.

Do $\beta 2 A R \rightarrow M 71-G F P$ OSNs coexpress an OR gene? Does the $\beta 2 \mathrm{AR} \rightarrow \mathrm{M} 71-\mathrm{GFP}$ mutant allele also follow the rule of monogenic expression? We addressed this difficult question by two- and three-color ISH, using riboprobes for $\beta 2 A R$ and mixtures of class I OR genes (mix 1 and mix 2) or class II OR genes (mix 1 and mix 2). In three-color ISH (Fig. 1E1), cell bodies of OSNs react with either class I mix 1 riboprobes, class II mix 1 riboprobes, or with the $\beta 2 A R$ riboprobe. In two-color ISH, we counted 28,324 OSNs reacting with class I mix 1 (recognizing 6 OR genes) and 398 with $\beta 2 A R$; and 21,161 OSNs reacting with class I mix 2 (recognizing 5 OR genes) and 437 with $\beta 2 A R$. Likewise, we counted 19,858 OSNs reacting with class II mix 1 (recognizing 5 OR genes) and 398 with $\beta 2 A R$; and 17,774 OSNs reacting with class II mix 2 (recognizing 12 OR genes) and 414 with $\beta 2 A R$. These staining patterns are consistent with monogenic expression of the $\beta 2 A R \rightarrow$ M71-GFP mutation; they strongly suggest that no OR gene is coexpressed.

Thus, our histological MOE studies demonstrate that the $\beta 2 A R \rightarrow M 71-$ GFP allele behaves as a typical OR allele.

\section{B2AR immunoreactivity is concentrated in the dendritic cilia of OSNS}

Another characteristic of ORs is that OR proteins are concentrated in the chemoreceptive end of OSNs: the cilia that emanate from the dendritic knob (Barnea et al., 2004; Feinstein et al., 2004; Strotmann et al., 2004). We performed wholemount IHC of the MOE with antibodies against $\beta 2 A R$ in $\beta 2 A R \rightarrow M 71-G F P$ mice (Fig. $2 A-D$ ). In side views (Fig. 2A, B), B2AR immunoreactivity is strong in the dendrite, dendritic knob, and cilia of OSNs that express $\beta 2 A R \rightarrow M 71-G F P$. En face views (Fig. 2C, D) reveal strong $\beta 2 A R$ immunoreactivity along the dozen or so dendritic cilia. In M71::GFP mice, which express a C-terminal fusion of GFP to M71 as a result of a gene-targeted mutation (Feinstein et al., 2004), there is a similar pattern of ciliary labeling in an en face view (Fig. 2E). Thus, expression of $\beta 2 A R$ from the M71 locus results in a concentrated $\beta 2 \mathrm{AR}$ immunoreactivity in the dendritic cilia of OSNs.

\section{Coexpression of Gnal with $\beta 2 A R$}

The $\beta 2 A R$ normally stimulates $G$-protein pathways via $G_{\alpha} s$, the protein product of the Gnas gene. Mature OSNs express $G_{\alpha}$ olf (Jones and Reed, 1989), the protein product of the Gnal gene. $G_{\alpha}$ olf is an essential component of the odorant-evoked signal transduction pathway (Belluscio et al., 1998), and $\beta 2 A R$ can also signal via $G_{\alpha}$ olf (Liu et al., 2001). In the MOE of wild-type C57BL/6 mice aged three weeks, three-color ISH reveals expression of Gnal throughout the thickness of the MOE except basally, and largely together with Omp (Fig. 3A). By contrast, Gnas is expressed strongly in the basal MOE, below the

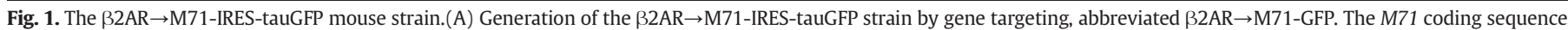

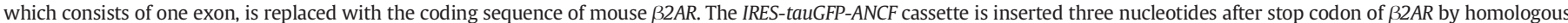

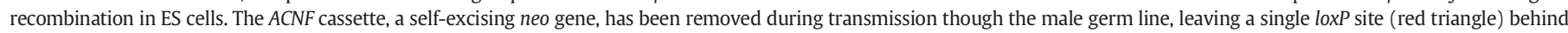

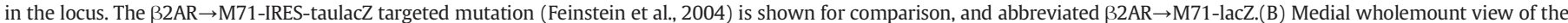

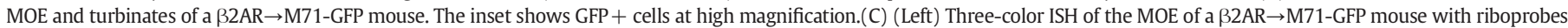

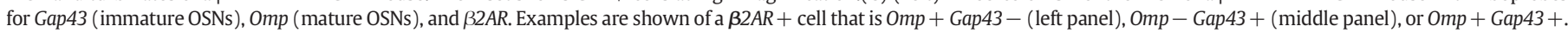

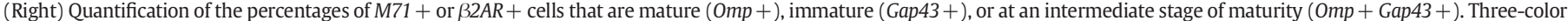

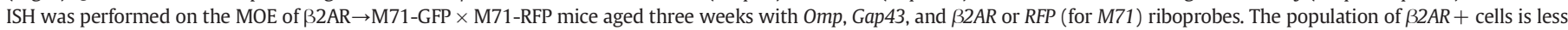

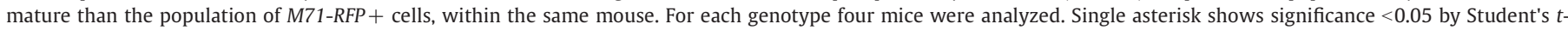

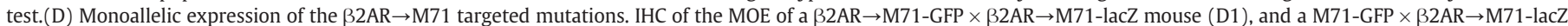

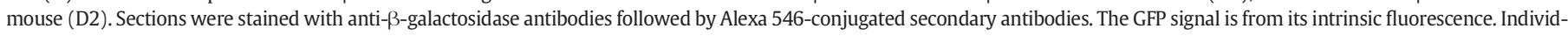

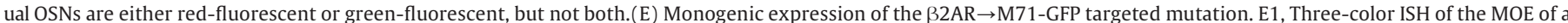

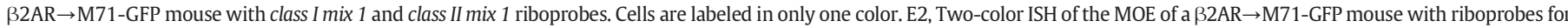

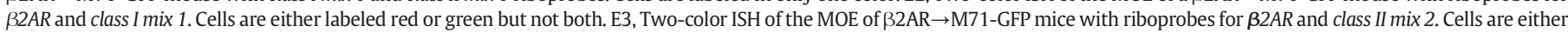
labeled red or green but not both.Scale bars, $200 \mu \mathrm{m}$ in B; $20 \mu \mathrm{m}$ in inset of B; $10 \mu \mathrm{m}$ in C, D1, D2, E2, E3; $50 \mu \mathrm{m}$ in E1. 
A

$\beta 2 \rightarrow$ M71-IRES-tauGFP

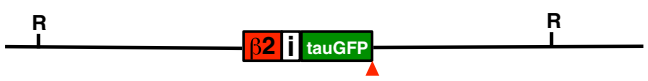

$\beta 2 \rightarrow$ M71-IRES-taulacZ

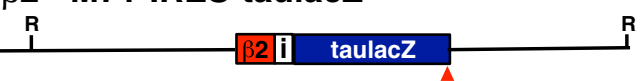

Wild-type M71
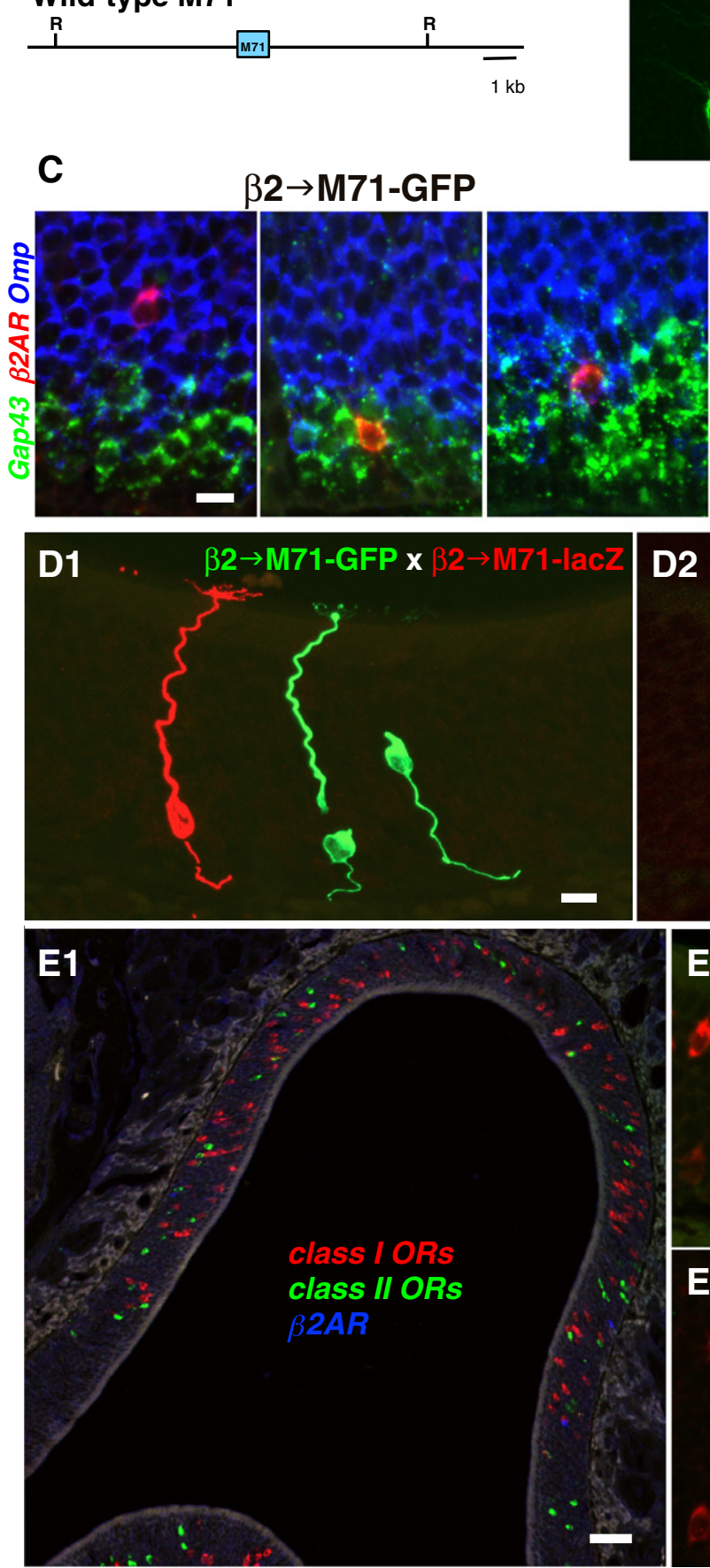

$\beta 2 \rightarrow$ M.71-GFP

B

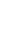
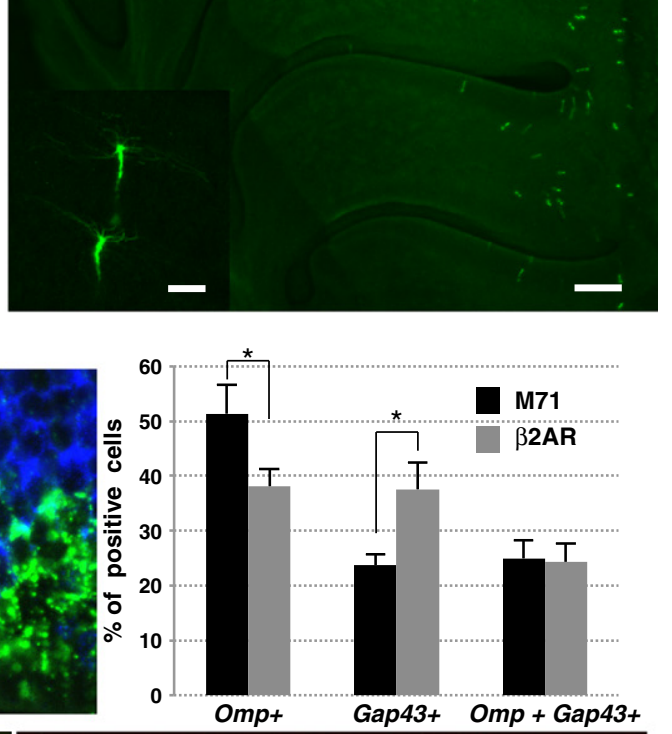

D2

M71-GFP x $32 \rightarrow$ M71-lacZ

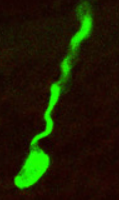

E2

B2AR class I ORs

E3

$\beta 2 A R$ class II ORs

(3)

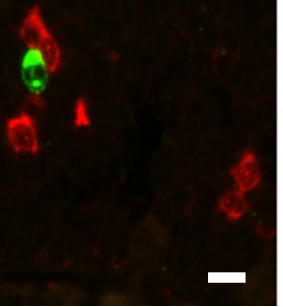



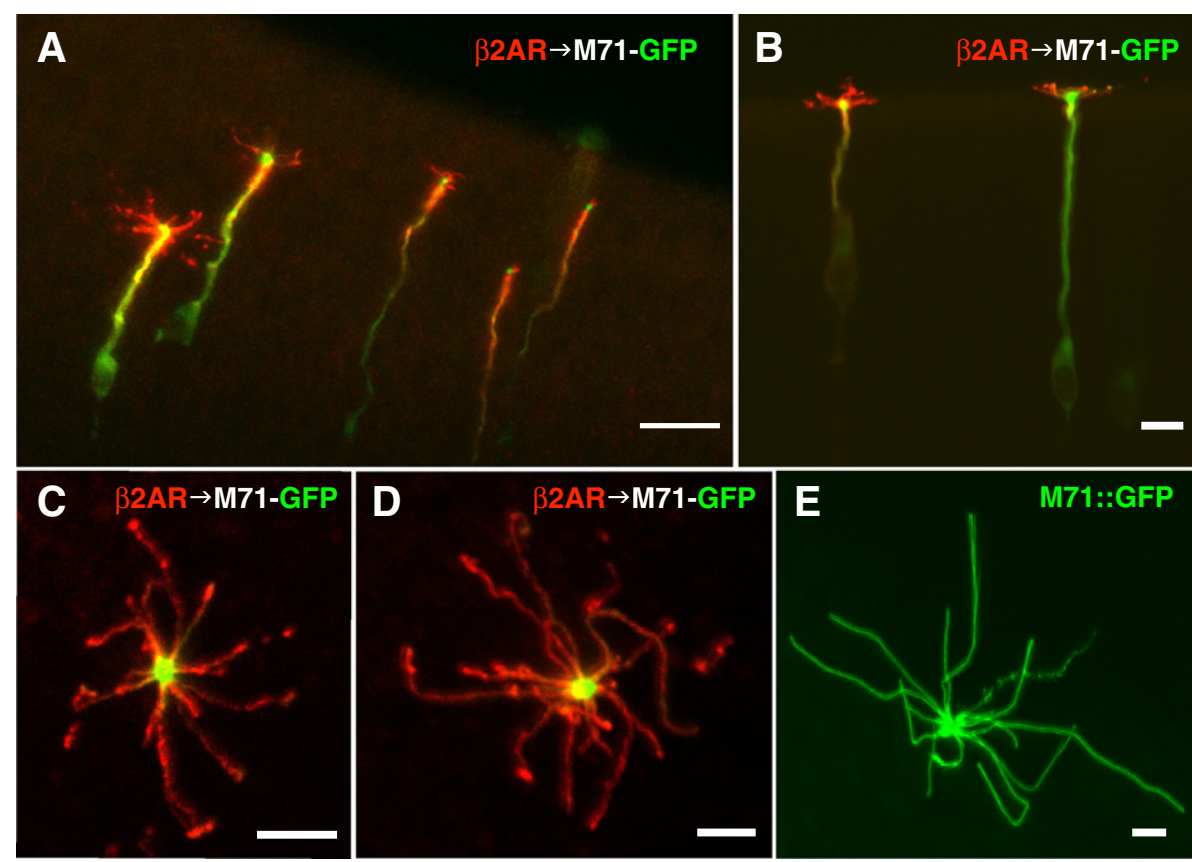

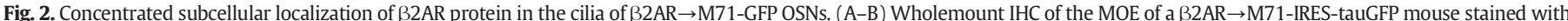

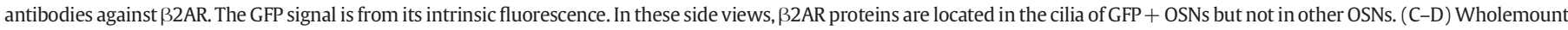

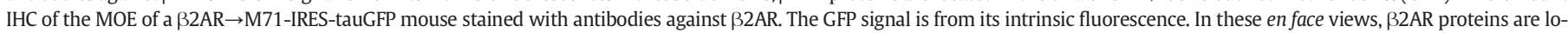

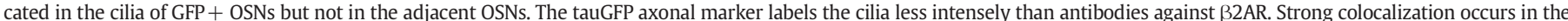

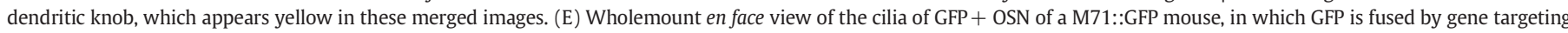

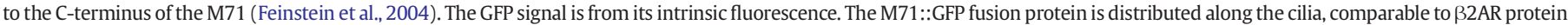
in C-D. Scale bars, $20 \mu \mathrm{m}$ in A; $10 \mu \mathrm{m}$ in B; $5 \mu \mathrm{m}$ in C-E.

layer of Gap43 + cells (Fig. 3B), and mutually exclusively with Gnal (Fig. 3C). There are also apical Gnas signals, in sustentacular cells. In $\beta 2 \mathrm{AR} \rightarrow \mathrm{M} 71-\mathrm{GFP}$ mice, cell bodies of GFP-immunoreactive OSNs coexpress Gnal and rarely Gnas (Fig. 3C). Thus, based on Gnal and Gnas expression, $\beta 2 A R+$ OSNs have the potential to transduce responses evoked by $\beta 2 A R$ agonists such as isoproterenol.

\section{$\beta 2 A R \rightarrow M 71-G F P$ neurons respond to isoproterenol}

We next performed patch-clamp recordings on the dendritic knobs of $\beta 2 A R \rightarrow$ M71-GFP OSNs with isoproterenol, using a wellcharacterized intact ex vivo preparation (Grosmaitre et al., 2006, 2007, 2009; Lam and Mombaerts, 2013; Lee et al., 2011; Ma et al., 1999). In voltage-clamp mode, seven out of seven $32 \mathrm{AR} \rightarrow$ M71-GFP OSNs responded to a $10^{-4} \mathrm{M}$ stimulus of isoproterenol with inward currents (Fig. 4A). Five cells were exposed to $10^{-4} \mathrm{M}$ of acetophenone, a stimulus for M71 + OSNs (Bozza et al., 2002); none responded. IBMX and forskolin, general activators of the signal transduction pathway, resulted in inward currents in all seven recorded OSNs (Fig. 4A). Increasing concentrations of isoproterenol, ranging from $10^{-7}$ to $10^{-3} \mathrm{M}$, induced inward currents with increasing maximum amplitude. We recorded dose-response curves from three $\beta 2 A R \rightarrow$ M71-GFP OSNs (Fig. 4B). The peak transduction currents versus the concentration were plotted and fitted with the Hill equation: $I=\operatorname{Imax} /\left(1+\left(K_{1 / 2} / C\right)^{\mathrm{n}}\right)$, where I represents the peak current, Imax the maximum response at saturating concentrations, $\mathrm{K}_{1 / 2}$ the concentration at which half of the maximum response was reached, $\mathrm{C}$ the concentration of odorant and $\mathrm{n}$ the Hill coefficient. The average maximum amplitude elicited by saturating concentrations is $109.9 \pm 6.6 \mathrm{pA}$; the $\mathrm{K}_{1 / 2}$ is $8.37 \pm 2 \mu \mathrm{M}$, and the Hill coefficient is $0.71 \pm 0.16$. By contrast, in 12 out of 12 randomly chosen OSNs of wild-type C57BL/6 mice, no responses to isoproterenol were observed at $10^{-5}$ to $10^{-4} \mathrm{M}$ (Fig. $4 \mathrm{C}$ ). Expression of an endogenous, unknown OR gene in these OSNs is indicated by responses to an odorant mixture in 8 of these 12 OSNs (Fig. 4C). Thus, expression of $\beta 2$ AR from the M71 locus in OSNs confers a dose-dependent responsiveness to isoproterenol, but such responses are not detected in wild-type OSNs.

\section{Coalescence of axons from $\beta 2 A R \rightarrow M 71-G F P$ OSNs into glomeruli}

A hallmark of mouse OSNs that express the same OR gene is that their axons coalesce into one or a few homogeneous glomeruli in the medial and lateral halves of the $\mathrm{OB}$, at conserved positions. Axonal coalescence can be demonstrated readily by IRES-mediated cotranslation of an axonal marker such as taulacZ (Mombaerts et al., 1996) or tauGFP (Rodriguez et al., 1999). We have previously shown that axons from $\beta 2 A R \rightarrow$ M71-lacZ OSNs coalesce into homogeneous glomeruli that are distinct and remote from the endogenous M71 glomeruli (Feinstein et al., 2004). We now confirm and extend this observation for axons from $\beta 2 A R \rightarrow M 71-G F P$ OSNs (Fig. 5A). The $\beta 2 A R \rightarrow M 71$ glomeruli are smaller than the M71 glomeruli, but they are discrete and apparently homogeneous glomeruli. At two weeks, the number and diameter of glomeruli in $\beta 2 \mathrm{AR} \rightarrow \mathrm{M} 71$-GFP mice are $2.3 \pm 0.3$ (SEM, $\mathrm{n}=13$ bulbs, $46 \%$ of bulbs have two glomeruli) and $20.0 \mu \mathrm{m} \pm 1.26$ ( $\mathrm{n}=35$ bulbs), compared to $2.1 \pm 0.1$ ( $\mathrm{n}=9$ bulbs, $89 \%$ of bulbs have two glomeruli) and $44.1 \mu \mathrm{m} \pm 1.28(\mathrm{n}=19)$ in M71-IREStauGFP mice; there is a significant difference in the glomerular diameter between $\beta 2 A R \rightarrow M 71-G F P$ mice and M71-IRES-tauGFP mice ( $t$-test, $\mathrm{p}=4.309 \mathrm{E}-17)$ but not in the number $(\mathrm{p}=0.6314)$. The smaller glomerular diameter in $\beta 2 \mathrm{AR} \rightarrow \mathrm{M} 71-\mathrm{GFP}$ mice correlates with the smaller number of GFP + OSNs. Although there is more variance in the number of glomeruli in $\beta 2 A R \rightarrow M 71-G F P$ mice, there is no significant difference in this number between $\beta 2 \mathrm{AR} \rightarrow \mathrm{M} 71-\mathrm{GFP}$ mice and M71-IRES-tauGFP mice (Fisher's exact test, $\mathrm{p}=0.074$ ). At three weeks, the number and diameter of glomeruli in $\beta 2 A R \rightarrow$ M71-GFP mice are $2.1 \pm 0.3(n=9)$ and $17.8 \mu \mathrm{m} \pm 1.26(\mathrm{n}=22)$; there is no significant difference between two and three weeks (Fisher's exact test, number $\mathrm{p}=0.999$; $t$-test, 


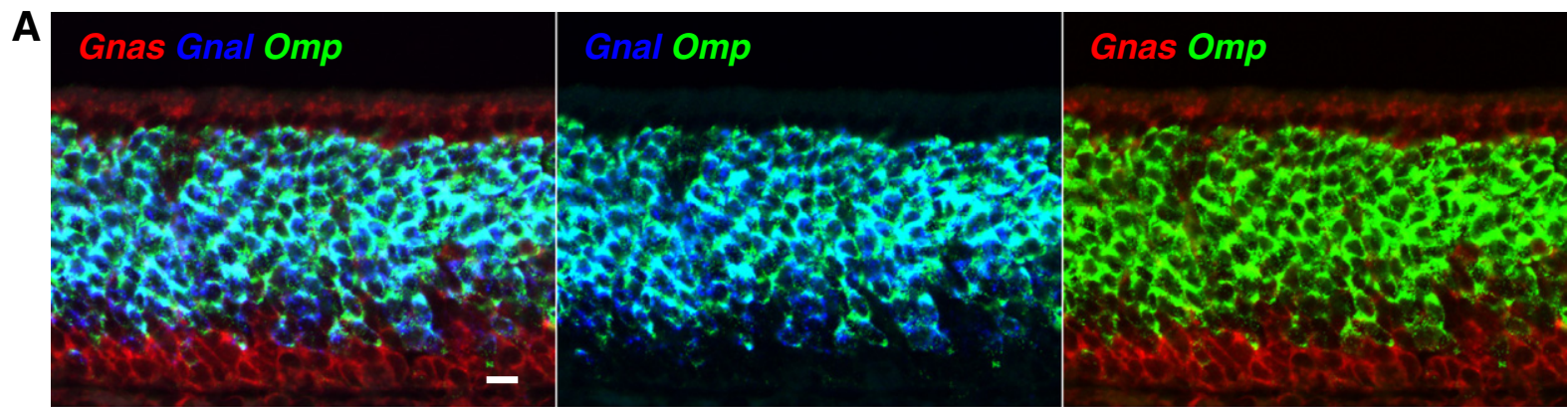

B
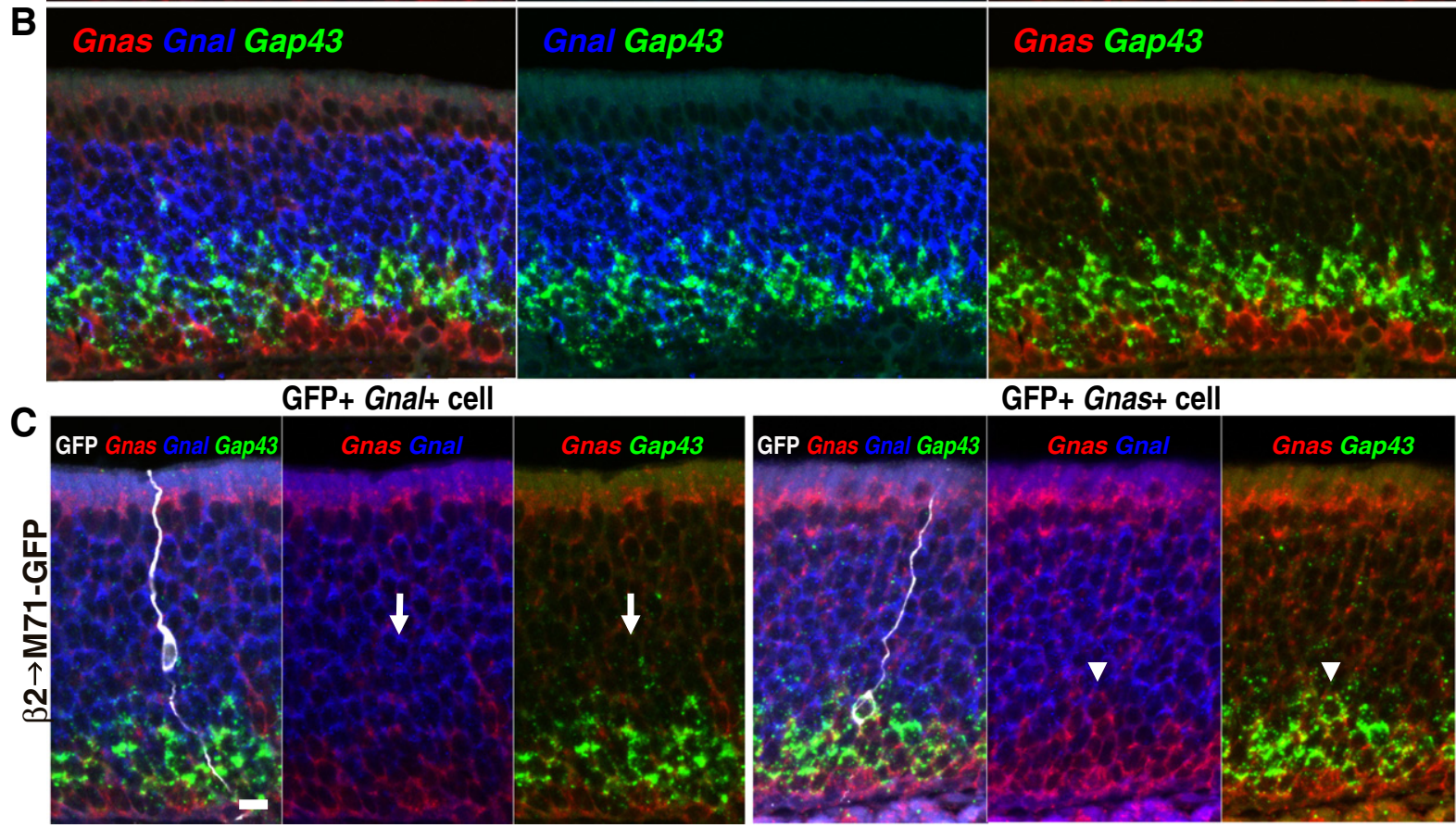

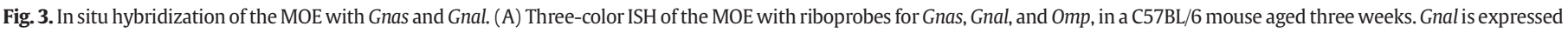

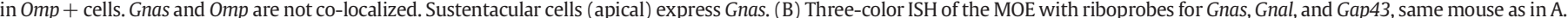

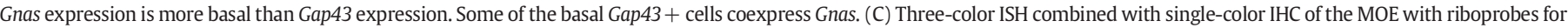

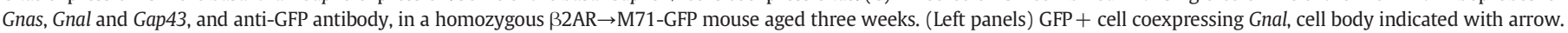
(Right panels) A rare GFP + cell coexpressing Gnas and Gap43, cell body indicated with arrowhead. Scale bar in A, $10 \mu \mathrm{m}$.

A

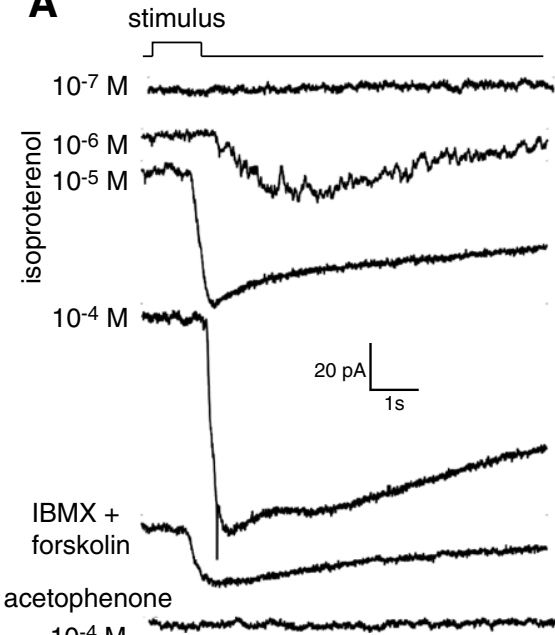

B

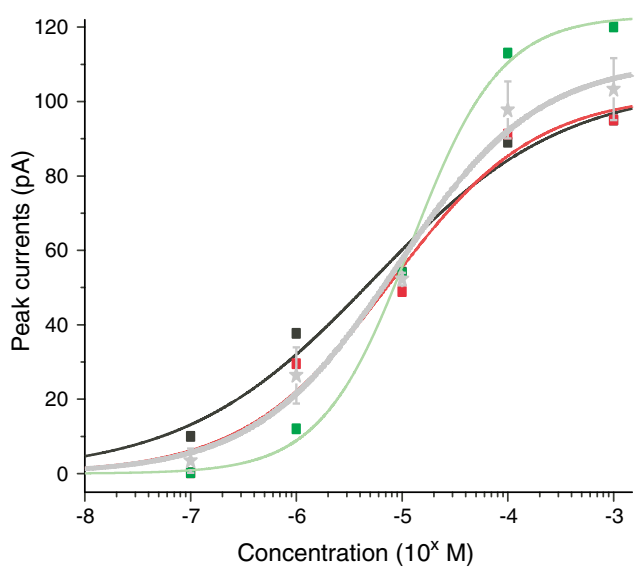

C stimulus

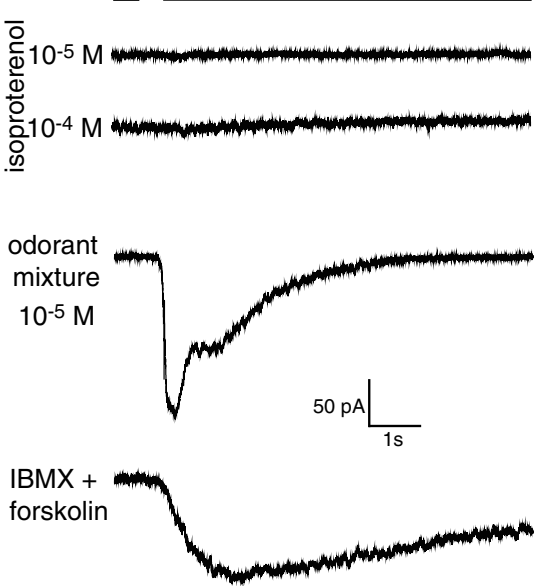

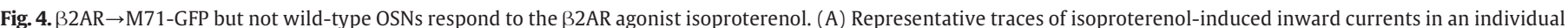

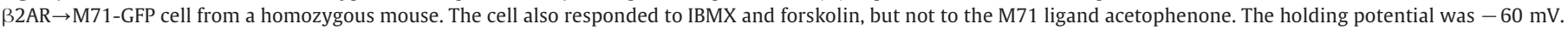

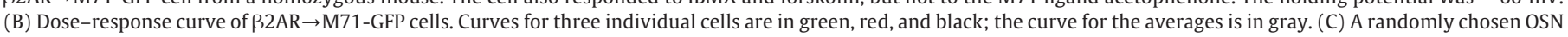
from a non-genetically modified C57BL/6 mouse did not respond to isoproterenol, but did respond to IBMX + forskolin, and to the odorant mixture. 
diameter $\mathrm{p}=0.244$ ). The distance between $\beta 2 \mathrm{AR} \rightarrow \mathrm{M} 71$ glomeruli and M71 glomeruli in the medial half of the olfactory bulb (Fig. 5B) is quite large: $949 \pm 277 \mu \mathrm{m}(\mathrm{n}=16)$. In a $\beta 2 A R \rightarrow M 71-G F P \times \beta 2 A R \rightarrow M 71-$ lacZ cross, the two types of axons coalesce into the same glomeruli, where they comingle diffusely without any signs of segregation (Fig. $5 \mathrm{C} 1, \mathrm{C} 2, \mathrm{C} 4)$. The $\beta 2 \mathrm{AR} \rightarrow \mathrm{M} 71$ glomeruli also show strong $\beta 2 \mathrm{AR}$
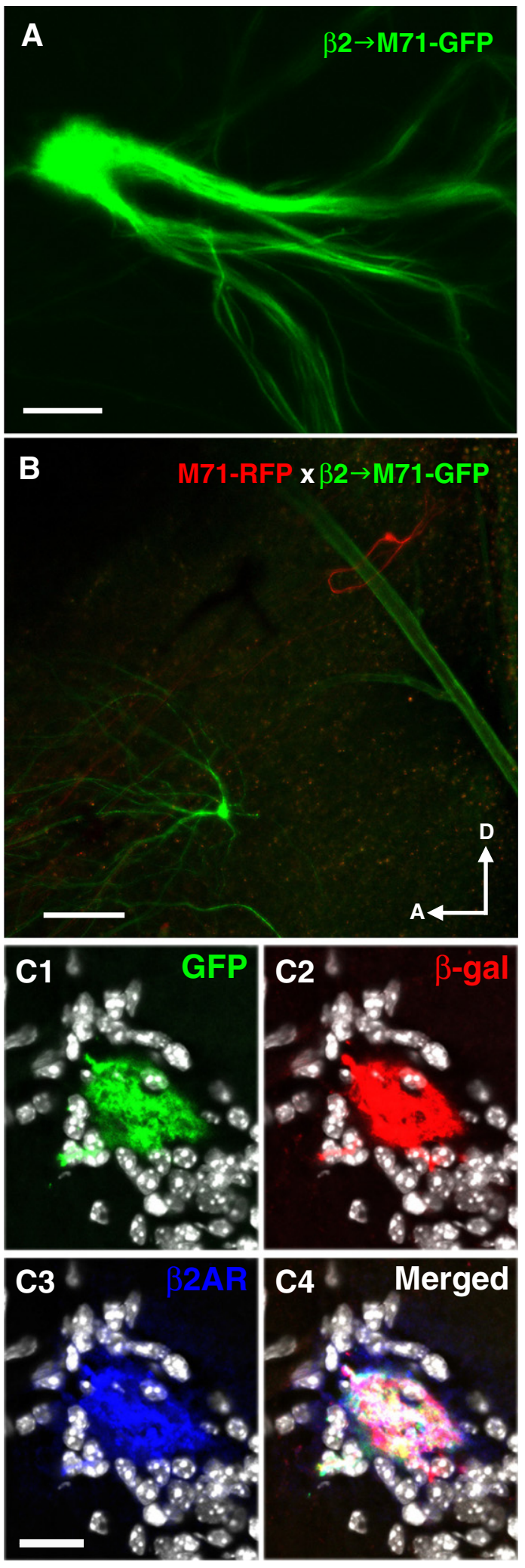

immunoreactivity (Fig. 5C3). Thus, based on the fundamental principle of axonal coalescence into glomeruli, expression of $\beta 2 A R$ from the $M 71$ locus is indistinguishable from expression of an OR from an $O R$ locus.

\section{The MOE and olfactory bulb of $\beta 2 A R$ and $\beta 1 A R$ knockout mice}

There has been one report about endogenous $\beta 2 A R$ expression in the mouse MOE, by radioactive ISH (Hague et al., 2004). We have not been able to confirm expression in OSNs of the MOE, by fluorescent ISH and by IHC. By strongly increasing the gain of the imaging, a faint and diffuse fluorescent signal can be seen with antibodies against $\beta 2 \mathrm{AR}$ in the MOE of wild-type mice (Fig. 6A). But this signal is also seen in $\beta 2 A R$ knockout mice (Chruscinski et al., 1999) (B2AR-KO) (Fig. 6A), indicating that it is background. In GFP + OSNs of M71-IRES-tauGFP mice, we do not detect $\beta 2 A R$ immunoreactivity either, whereas $\beta 2 A R$ signal is clear and intense in $32 \mathrm{AR} \rightarrow \mathrm{M} 71-\mathrm{GFP}$ OSNs (Fig. 6A).

Despite any signs of expression of $\beta 2 A R$ and $\beta 1 A R$ in OSNs, we proceeded to examine the MOE of $\beta 2 A R-K O$ mice and of $\beta 1 A R-K O$ mice (Rohrer et al., 1996). We find a normal layering of Gap43 + cells (immature OSNs), Omp + cells (mature OSNs), and Cbr2 + cells (sustentacular cells) in three-color ISH (Fig. 6B). Moreover, two hallmarks of an OR, the concentration of OR protein in dendritic cilia and axonal coalescence into glomeruli, are not affected in $\beta 2 A R-K O$ mice and 31 AR-KO mice crossed with M71::GFP mice (Fig. 6C). Finally, tyrosine hydroxylase immunoreactivity, an activity marker for periglomerular neurons in the olfactory bulb, is not affected in $\beta 2 A R-K O$ mice and B1AR-KO mice (Fig. 6D). As expected, this immunoreactivity is essentially absent in Cnga2 knockout mice, in which the odorant-evoked signal transduction pathway is impaired (Fig. 6D).

However, using the same fluorescent ISH technique, we do find widespread and strong expression of another GPCR in the MOE, and across mature OSNs: the dopamine type-2 receptor, Drd2 (Fig. 7). Thus, with the same ISH method and in the same hands, Drd2 expression is readily detectable in OSNs, but $\beta 2 A R$ expression is not detectable.

\section{Discussion}

The $\beta 2 A R$ as a surrogate odorant receptor

We have shown previously that $\beta 2 A R$ expression from the $M 71$ locus along with IRES-taulacZ ( $\beta 2 A R \rightarrow M 71-l a c Z)$ is in several aspects phenotypically indistinguishable from expression of an OR coding sequence from the $M 71$ locus (Feinstein et al., 2004). We have here confirmed and extended these findings in a novel strain of $\beta 2 A R \rightarrow M 71-$ GFP mice. The important advantage of the GFP marker is that it lends itself well to electrophysiological recordings. The GFP + cells express Gnal and respond to the $\beta 2 A R$ agonist isoproterenol in a dose-dependent manner with $\mathrm{K}_{1 / 2}$ of $8.37 \mu \mathrm{M}$, which is similar to the $10 \mu \mathrm{M}$ concentration used for other studies in the mouse olfactory system (Araneda and Firestein, 2006). Thus, by the criterion of "odorant" responses, we have here demonstrated a critical function of $\beta 2 A R$ as a surrogate OR in OSNs: it confers dose-dependent responsiveness to a cognate agonist. We also demonstrate strong $\beta 2 A R$ immunoreactivity in OSN cilia. Function of $\beta 2 A R$ as a surrogate OR in OSNs under these experimental conditions is consistent with motifs in intracellular regions 2,3 , and 4 that are

Fig. 5. Glomeruli formed by coalescence of axons of $\beta 2 A R \rightarrow$ M71-GFP OSNs. (A) Medial wholemount view of the olfactory bulb of a $\beta 2 A R \rightarrow$ M71-GFP mouse aged three weeks. Axons labeled with intrinsic GFP fluorescence coalesce into a single medial glomerulus. (B) Medial wholemount view of the olfactory bulb of a M71-RFP $\times \beta 2 A R \rightarrow$ M71-GFP mouse. Axons and glomeruli are labeled by the intrinsic fluorescence of RFP and GFP. The medial $\beta 2 A R \rightarrow M 71-G F P$ glomerulus is shifted anteriorly and ventrally compared to the endogenous M71-RFP glomerulus. Both glomeruli are small, as they receive axonal input from half of the OSNs that express the M71 locus. (C) IHC of a section of the olfactory bulb of a $\beta 2 A R \rightarrow M 71-G F P \times \beta 2 A R \rightarrow M 71$-lacZ mouse, stained with antibodies against $\beta$-galactosidase and $\beta 2 A R$. The GFP signal is from its intrinsic fluorescence, and the white signal is from DAPI. Axons of GFP + OSNs coalesce and comingle with axons from lacZ + OSNs within a single lateral glomerulus. Scale bars, 20 m in A and C3; $200 \mu \mathrm{m}$ in B. 


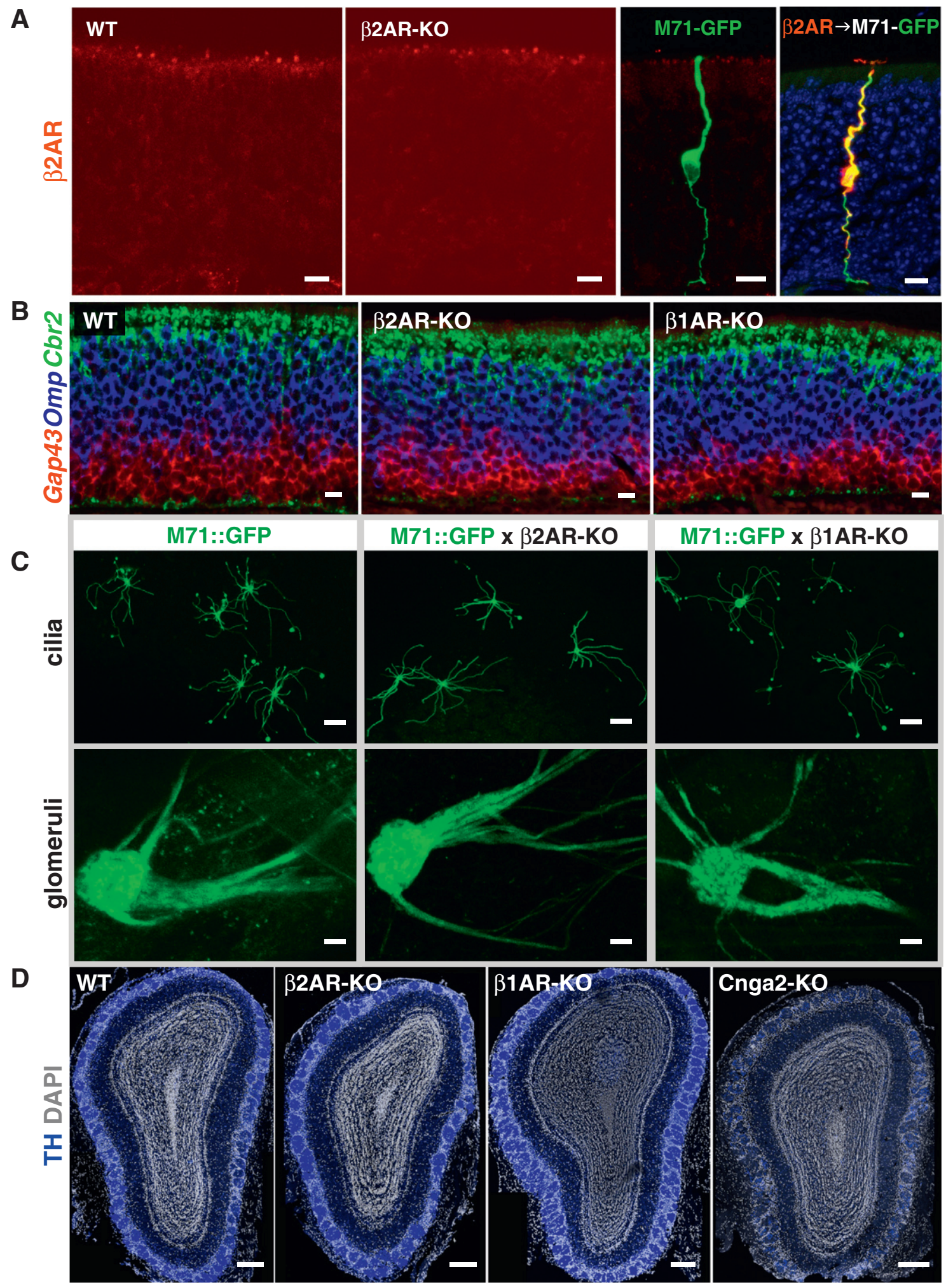

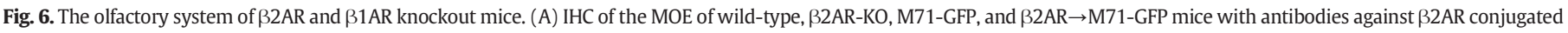

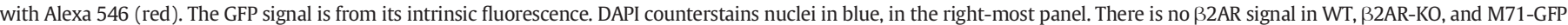

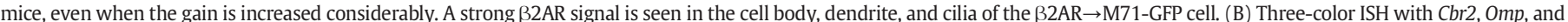

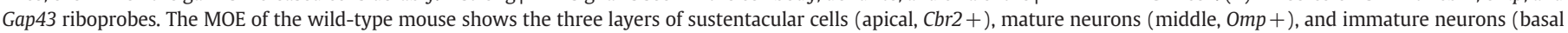

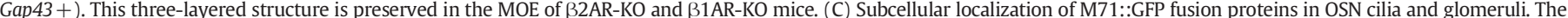

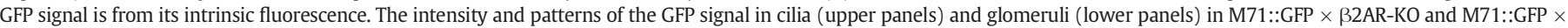

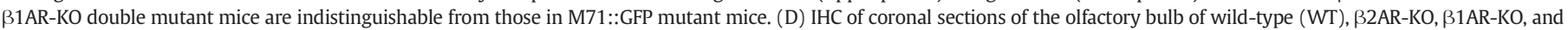

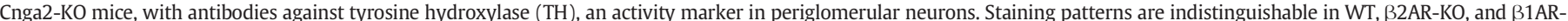

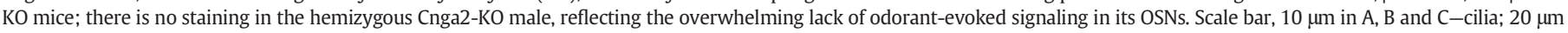
in C-glomeruli; and $200 \mu \mathrm{m}$ in D. 

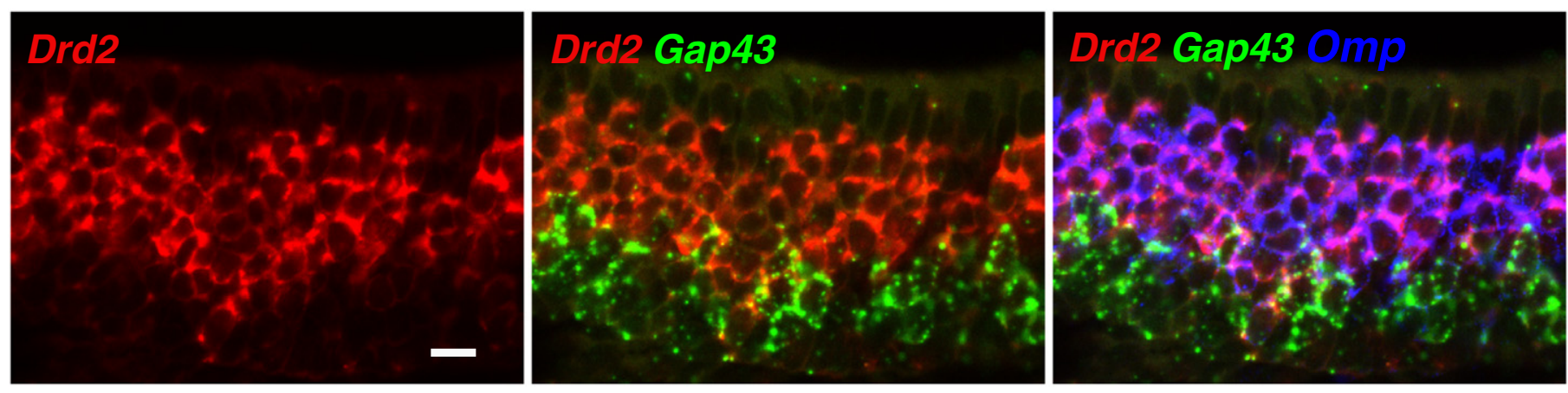

Fig. 7. Drd2 expression in mature OSNs. Three-color ISH of the MOE with Drd2, Omp, and Gap43. Mature OSNs express Drd2. Scale bar, $10 \mu \mathrm{m}$.

conserved among ORs and other GPCRs (DRYVAI, KAL, and NPXIY, respectively), and with coupling of $\beta 2 A R$ to $G_{\alpha}$ olf (Jones and Reed, 1989; Liu et al., 2001).

Our results with differentially tagged $\beta 2 \mathrm{AR} \rightarrow \mathrm{M} 71$ alleles provide powerful evidence that the OR coding sequence does not fulfill a specific role in monoallelic expression of an OR locus (Nguyen et al., 2007); its role can be substituted by $\beta 2 A R$. The principle of monogenic expression of $\beta 2 \mathrm{AR}$ (one OR gene per OSN) is more difficult to demonstrate convincingly. The $\beta 2 \mathrm{AR} \rightarrow \mathrm{M} 71$ axons innervate their glomeruli exclusively and homogeneously, suggesting that these glomeruli do not receive axonal innervation from OSNs that express other ORs. Here are two arguments for monogenic expression. If any of several other ORs were to be coexpressed with $\beta 2 A R \rightarrow M 71$, labeled axons would likely innervate a variety of glomeruli, appropriate for these coexpressed ORs. It is difficult to imagine a mechanism that governs the coexpression of a specific OR with $\beta 2 A R \rightarrow M 71$, but it cannot be excluded. We have addressed the issue of monogenic expression of $\beta 2 \mathrm{AR} \rightarrow \mathrm{M} 71$ by ISH with riboprobes for $\beta 2 A R$ and mixtures of class I and class II OR genes: we do not observe coexpression in a total of $1647 \beta 2 A R+$ cells and a total of 87,117 cells labeled with the OR riboprobes. As there is no indication for OR expression in $\beta 2 A R \rightarrow M 71$ OSNs, single-cell RT-PCR experiments with degenerate primers for OR genes are likely to yield only artifacts.

Our new findings and those of others (Aoki et al., 2013; Nakashima et al., 2013) corroborate the experimental value of $\beta 2 \mathrm{AR}$ as a surrogate $\mathrm{OR}$. The implication and promise are that the wealth of pharmacological knowledge about structure-function relationships of $\beta 2 A R$ can be applied to study aspects of OR function in OSNs.

\section{Endogenous $\beta 2 A R$ expression in OSNs}

The use of $\beta 2 A R$ as a surrogate OR is predicated on the absence of endogenous $\beta 2 A R$ expression in OSNs. There has been a single report of $\beta 2 A R$ expression in the MOE, which was based on radioactive ISH (Hague et al., 2004). Despite major attempts to visualize B2AR gene and protein expression histologically in OSNs, we have not been able to confirm this finding. Randomly chosen OSNs from non-genetically modified, wild-type C57BL/6 mice do not respond to the $\beta 2 A R$ agonist isoproterenol at $10^{-5}$ to $10^{-4} \mathrm{M}$. Further, the MOE of $\beta 2 \mathrm{AR}$ knockout mice and $\beta 1 A R$ knockout mice appears normal. We cannot exclude expression of $\beta 2 A R$ in a small subpopulation of OSNs, or in non-OSN cell types of the MOE. Due to low cellular resolution, the ISH method used by Hague et al. (2004) does not afford the conclusion that $\beta 2 A R$ is expressed in mature OSNs. We cannot exclude low-level expression of B2AR in some or many OSNs, below the detection threshold of our ISH and IHC methods. Sensitive methods such as radioactive ISH, qPCR, or NanoString (Khan et al., 2011; 2013) may reveal trace amounts of $\beta 2 \mathrm{AR}$ in the MOE or in OSNs. In any case, as $\beta 2 \mathrm{AR}$ has been proposed to "drive" OR surface expression (Bush and Hall, 2008; Bush et al., 2007; Hague et al., 2004), expression in OSNs ought to be strong, perhaps stoichiometric with ORs. The increase in M71 surface expression in human embryonic kidney-293 cells by coexpression with $\beta 2 \mathrm{AR}$
(Hague et al., 2004) may be an example of the caveats of heterologous (over)expression, and have limited in vivo relevance. Effects of adrenaline on OSNs have been documented in the newt (Kawai et al., 1999).

\section{Expression of non-olfactory GPCRs in OSNs}

Regardless of the controversy about endogenous $\beta 2 A R$ expression in OSNs, there are several independent lines of evidence for expression of non-olfactory GPCRs in OSNs. This expression is of particular interest if it involves functional interactions with ORs such as by heterodimerization or oligomerization. M71-expressing OSNs in gene-targeted M71-IREStaulacZ mice (Feinstein and Mombaerts, 2004) show immunoreactivity for purinergic receptors $P 2 Y_{1} R, P 2 Y_{2} R$, and $A_{2 A} R$ (Bush et al., 2007; Bush and Hall, 2008). The M3 muscarinic acetylcholine receptor, product of the Chrm 3 gene, is expressed in the MOE, and increases the potency and efficacy of odorant-elicited responses of several ORs in human embryonic kidney-293T cells (Li and Matsunami, 2011). Drd2 expression in OSNs has been documented histologically in rat (Koster et al., 1999) and mouse (Sammeta et al., 2007), and electrophysiologically in rat (Ennis et al., 2001; Okada et al., 2003) and mouse (Hegg and Lucero, 2004). We confirm with fluorescent ISH that Drd2 is expressed strongly and uniformly across mature OSNs in mouse. Thus, with the same ISH method and in the same hands, we can readily detect $\operatorname{Drd} 2$ expression in OSNs, but not $\beta 2 A R$ expression. There is chromogenic ISH evidence for several other non-olfactory GPCRs in mouse OSNs (Sammeta et al. 2007).

Even if these non-olfactory GPCRs do not interact directly with ORs, their signaling pathways may overlap - for instance they may couple to the same $G$ protein subunits as ORs: to $G_{\alpha}$ or $G_{\alpha}$ olf - and they may also have agonist-independent activity, in addition to that of ORs (Nakashima et al., 2013). Expression of non-olfactory GPCRs in OSNs must be taken into account when formulating hypotheses about OR gene choice and OSN axonal wiring that do not assign unique functions to ORs, particularly when these non-olfactory GPCRs are expressed at stages of OSN differentiation when these processes take place.

\section{Experimental methods}

\section{Gene targeting}

We mutated the M71 locus by homologous recombination in ES cells according to the same design as for numerous other targeted M71 alleles (Feinstein et al., 2004). We replaced the M71 coding sequence with the mouse $\beta 2 A R$ coding sequence and the IRES-tauGFPANCF cassette (Bozza et al., 2002), which we inserted three nucleotides after the stop codon of $\beta 2 A R$. The ACNF cassette, a self-excising neo gene, is removed during transmission though the male germ line, leaving a single loxP site behind. The targeting vector was linearized and electroporated into E14 embryonic stem (ES) cells according to standard methods (Mombaerts et al., 1996). ES cells were injected into C57BL/6 blastocysts, and chimeras bred with wild-type C57BL/6 mice. 
Using genomic DNA of mouse tails, we confirmed that the sequence of $\beta 2 A R$ at the M71 locus encodes the wild-type mouse $\beta 2 A R$ amino acid sequence. The strain is in a mixed $129 \times \mathrm{C} 57 \mathrm{BL} / 6$ background, and publicly available from The Jackson Laboratory (Bar Harbor, ME) as JR\#6734, official strain name B6;129P2-Olfr151 < tm35(Adrb2) Mom > /MomJ. Both males and females were used for experiments.

\section{In situ hybridization and X-gal staining}

Multicolor in situ hybridization (ISH) and ISH combined with IHC were performed as described (Ishii et al., 2004). To identify mature, immature, and intermediate stages of $\beta 2 A R+$ cells and $M 71+$ cells, we analyzed by three-color ISH every tenth section of $12 \mu \mathrm{m}$ coronal sections of the MOE (from the first appearance of the turbinates to the end of the MOE) from $\beta 2 A R \rightarrow M 71 \times$ M71-IRES-tauRFP mice aged three weeks $(\mathrm{n}=4)$. Riboprobes were: $\beta 2 A R$, nt 208-1464 from GenBank accession number NM_007420; Omp, Gap43 (Ishii et al., 2004); RFP (mCherry) as nt 21-512 from AY678264; and bovine tau (Ishii and Mombaerts, 2008), which was added to the RFP probe to enhance the signal of tauRFP. Images were collected with a Zeiss LSM 710 confocal microscope.

To address monogenic $\beta 2 A R$ expression in $\beta 2 A R \rightarrow M 71$ mice, we analyzed $\beta 2 A R \rightarrow M 71$ mice aged three weeks $(n=3)$ with two- or three-color ISH. Riboprobes in class I mix 1 are: MOR7-1 (Olfr578), nt 382-869 from NM_147115.1; MOR22-2 (Olfr69), nt 605-1117 from NM_013621.3; MOR32-4 (Olfr672), nt 1-937 from NM_146760.1; MOR40-1 (Olfr683), nt 1-960 from NM_147045.1. These riboprobes detect a total of six OR genes, including Olfr68 and Olfr684. Riboprobes in class I mix 2 are: MOR18-2 (Olfr78), nt 1216-2164 from NM_130866. 4; MOR31-2 (Olfr690), nt 89-1022 from NM_020290.2; MOR31-6 (Olfr691), nt 147061.1; S50 (MOR42-1, Olfr545), nt 340-925 from NM_146840.1. These riboprobes detect a total of five OR genes, including Olfr544. Riboprobes in class II mix 1 are: MOR200-1 (Olfr1031), nt 347-867 from NM_001011759.2; MOR258-5 (Olfr62), nt 167-883 from NM_146315.2; MOR265-2P (Olfr819), nt 1-531 from NM 001165944.1; MOR23 (MOR267-13,Olfr16), nt 49-940 from NM_ 008763.2. These riboprobes detect five OR genes, including Olfr247. Riboprobes in class II mix 2 are: MOR101-1 (Olfr520), nt 115-884 from NM_147063; MOR126-1 (Olfr54), nt 1-942 from NM_010997. 1; MOR136-14 (Olfr3), nt 17-871 from NM_206903.1; MOR259-13 (Olfr1328), nt 27-942 from NM_146399. These riboprobes detect a total of 12 OR genes, including Olfr521, Olfr1329, Olfr1330, Olfr1331, Olfr1333, Olfr1335, Olfr1337, and Olfr1338. The riboprobe for Gnas is nt 408-1512 from NM_001077510.2, Gnal is nt 1-1106 from NM_ 010307. For three-color ISH combined with IHC, chicken anti-GFP antibody (1:300, Abcam) followed by Alexa 647-conjugated goat antichicken IgG was used in $\beta 2 A R \rightarrow$ M71-GFP mice. The DNP-labeled Gnal riboprobe was detected by anti-DNP antibody (1:800, Invitrogen) followed by Alexa 405-conjugated goat anti-rabbit IgG (1:200, Invitrogen). The ISH riboprobe for Drd2 is nt 524-1323 from NM_010077.2. The Cbr2 probe is as in Ishii et al. (2004).

X-gal staining was done as described (Mombaerts et al., 1996) with minor modification: tissues were fixed in $4 \%$ paraformaldehyde (PFA) in $1 \times \mathrm{PBS}_{\text {without }} \mathrm{MgSO}_{4}$ and EGTA.

\section{Immunohistochemistry on tissue sections}

Mice were anesthetized by injection of ketamine $\mathrm{HCl}$ and xylazine (150 mg/kg and $10 \mathrm{mg} / \mathrm{kg}$ body weight, respectively), and perfused with ice-cold PBS, followed by 4\% PFA in PBS. The mouse heads were dissected, post-fixed in 4\% PFA, and decalcified in 0.45 M EDTA in $1 \times$ PBS overnight at $4{ }^{\circ} \mathrm{C}$. The decalcification step was omitted for the bulbs. Samples were cryoprotected in $15 \%$ and $30 \%$ sucrose in $1 \times$ PBS at $4{ }^{\circ} \mathrm{C}$, frozen in OTC compound, and sectioned at 12 or $16 \mu \mathrm{m}$ with a Leica CM3500 cryostat. Sections were washed with $1 \times$ PBS and blocked with $10 \%$ NGS or NDS, $0.1 \%$ Triton X-100 in $1 \times$ PBS for $1 \mathrm{~h}$ at room temperature. After the blocking step, sections were incubated in 3\% BSA, $0.1 \%$ Triton X-100 in $1 \times$ PBS overnight at $4{ }^{\circ} \mathrm{C}$ with rabbit anti- $\beta$ galactosidase $(1: 1000$, Cappel, Fig. $1 D 1, D 2)$, chicken anti- $\beta$ galactosidase (1:500, Abcam, Fig. 5C2), rabbit anti- $\beta 2 A R$ (1:500, Santa Cruz, Figs. 5C3, 6A), and rabbit anti-TH (1:500, Millipore, Fig. 6D). The GFP signal is from its intrinsic fluorescence. After incubation with primary antibodies, sections were incubated for $2 \mathrm{~h}$ at room temperature with secondary antibodies: Alexa 546-conjugated goat anti-rabbit IgG (1:500, Invitrogen, Fig. 1D1, D2), Alexa 546-conjugated goat antichicken IgG (1:500, Invitrogen, Fig. 5C2), or Alexa 647-conjugated goat anti-rabbit IgG (1:500, Invitrogen, Fig. 5C3). The bulb sections were counterstained with $0.1 \mu \mathrm{g} / \mathrm{ml}$ DAPI (Invitrogen). Sections were analyzed with a Zeiss LSM 710 confocal microscope.

\section{Wholemount immunohistochemistry}

Wholemount IHC was performed as described (Strotmann et al., 2004). Briefly, olfactory turbinates and MOE were dissected from 2wk or 3 -wk old mice. Tissues were fixed in $4 \%$ PFA in $1 \times$ PBS for $4 \mathrm{~h}$ on ice, washed with $0.1 \%$ Triton X-100 in $1 \times$ PBS, and blocked with $10 \%$ NGS, $0.1 \%$ Triton X-100 in $1 \times$ PBS for $1 \mathrm{~h}$ at room temperature with gentle agitation. Incubation was at $4{ }^{\circ} \mathrm{C}$ overnight with gentle agitation in $1 \times$ PBS containing $10 \%$ NGS, $0.1 \%$ Triton X-100 with rabbit antiB2AR (1:500, Santa Cruz). After washing with $0.1 \%$ Triton X-100 in $1 \times$ PBS, tissues were incubated with Alexa 546-conjugated goat antirabbit IgG (1:500, Invitrogen) in $1 \times$ PBS containing 10\% NGS, $0.1 \%$ Triton X-100 for $2 \mathrm{~h}$ at room temperature. After washing with $0.1 \%$ Triton X-100 in $1 \times$ PBS, stained samples were kept in $1 \times$ PBS, and images of samples from en face views were collected with a Zeiss LSM 710 confocal microscope.

\section{Patch-clamp recordings}

Mice were anesthetized by injection of ketamine $\mathrm{HCl}$ and xylazine (150 mg/kg and $10 \mathrm{mg} / \mathrm{kg}$ body weight, respectively), and then decapitated. The head was immediately put into ice cold Ringer's solution, which contained (in $\mathrm{mM}$ ): $\mathrm{NaCl} 124, \mathrm{KCl} 3, \mathrm{MgSO}_{4} 1.3, \mathrm{CaCl}_{2} 2$, $\mathrm{NaHCO}_{3} 26, \mathrm{NaH}_{2} \mathrm{PO}_{4}$ 1.25, glucose 15; pH 7.6 and 305 mOsm. The pH was kept at 7.4 by bubbling with $95 \% \mathrm{O}_{2}$ and $5 \% \mathrm{CO}_{2}$. The nose was dissected out en bloc. The MOE attached to the nasal septum and the dorsal recess was removed and kept in oxygenated Ringer. Immediately before starting the recording session, the entire MOE was peeled away from the underlying bone and transferred to a recording chamber with the mucus layer facing up. Oxygenated Ringer was continuously perfused at room temperature.

The dendritic knobs of OSNs were visualized with an upright microscope (Olympus BX51WI) equipped with an Olympus DP72 camera and a $40 \times$ water-immersion objective. An extra $2 \times$ magnification was obtained by a magnifying lens in the light path. In $\beta 2 A R \rightarrow M 71-G F P$ mice, the GFP + OSNs were visualized under fluorescent illumination. Superimposition of the fluorescent and bright-field images allowed identification of the fluorescent cells under bright field, which directed the recording pipettes. In wild-type C57BL/6 mice, OSNs were recorded randomly using bright-field illumination. Electrophysiological recordings were controlled by an EPC-10 USB amplifier combined with Patchmaster software (HEKA Electronic, Germany). Perforated patch clamp was performed on the dendritic knobs by including $260 \mu \mathrm{M}$ nystatin in the recording pipette, which was filled with the following solution (in $\mathrm{mM}$ ): $\mathrm{KCl} 70, \mathrm{KOH} \mathrm{53,} \mathrm{methanesulfonic} \mathrm{acid} \mathrm{30,} \mathrm{EGTA} \mathrm{5,} \mathrm{HEPES}$ 10, sucrose 70; pH $7.2(\mathrm{KOH})$ and $310 \mathrm{mOsm}$. The junction potential was $\sim 9 \mathrm{mV}$ and was corrected in all experiments off-line. Under voltage-clamp mode, the signals were filtered at $10 \mathrm{kHz}$ followed by $2.9 \mathrm{kHz}$, and sampled at $20 \mathrm{kHz}$.

A seven-barrel pipette was used to deliver stimuli by pressure ejection through a picospritzer (Pressure System IIe, Toohey Company, Fairfield, NJ). The stimulus electrode was placed $\sim 20 \mu \mathrm{m}$ downstream from 
the recording site. Distance and pressure were adjusted in order to minimize mechanical responses (Grosmaitre et al., 2007). All stimuli were delivered at a $138 \mathrm{kPa}(\sim 20 \mathrm{psi})$ pressure indicated on the picospritzer, with a $500 \mathrm{~ms}$ pulse length. Isoproterenol $\mathrm{HCl}$ (Tocris, Lille, France) was prepared in $1 \mathrm{M}$ stock solution in water and kept at $-20^{\circ} \mathrm{C}$; final solutions were prepared before each experiment by adding Ringer. The odorant mixture consists of 19 compounds in equal molar concentration (Grosmaitre et al., 2009): heptanol, octanol, hexanal, heptanal, octanal, heptanoic acid, octanoic acid, cineole, amyl acetate, $(+)$ limonene, $(-)$ limonene, $(+)$ carvone, $(-)$ carvone, 2-heptanone, anisaldehyde, benzaldehyde, acetophenone, 3-heptanone, and ethyl vanillin. Odorant mixture was prepared as a $0.1 \mathrm{M}$ solution in DMSO and kept at $-20^{\circ} \mathrm{C}$; final solutions at $10^{-5} \mathrm{M}$ for each odorant were prepared before each experiment by adding Ringer. Forskolin, an activator of adenylyl cyclase, was prepared as a $10 \mathrm{mM}$ stock solution in DMSO. IBMX, an inhibitor of phosphodiesterases, was prepared as a $100 \mathrm{mM}$ stock solution in DMSO. Final solution containing $200 \mu \mathrm{M}$ of IBMX and $20 \mu \mathrm{M}$ of forskolin was prepared before each experiment by adding Ringer. All chemicals were obtained from Sigma-Aldrich unless otherwise stated.

Data were analyzed using Fitmaster (HEKA). Maximum amplitude of the response and kinetics characteristics were measured. Dose-response curves were drafted and fitted using Origin software (OriginLabs).

\section{Acknowledgments}

We thank Brian Kobilka for providing $\beta 1 \mathrm{AR}-\mathrm{KO}$ mice and $\beta 2 \mathrm{AR}$ KO mice; Paul Feinstein for construction of the targeting vector and Wei Tang for blastocyst injections at The Rockefeller University; and Tobias Burbach for technical assistance. This work was supported by the National Institutes of Health (M.M. and P.M.); the Max Planck Society and European Research Council Advanced Grant ORGENECHOICE (P.M.); and CNRS and the Conseil Régional de Bourgogne (X.G.).

\section{References}

Aoki, M., Takeuchi, H., Nakashima, A., Nishizumi, H., Sakano, H., 2013. Possible roles of Robo1 + ensheathing cells in guiding dorsal-zone olfactory sensory neurons in mouse. Dev. Neurobiol 73, 828-840.

Araneda, R.C., Firestein, S., 2006. Adrenergic enhancement of inhibitory transmission in the accessory olfactory bulb. J. Neurosci. 26, 3292-3298.

Barnea, G., O'Donnell, S., Mancia, F., Sun, X., Nemes, A., Mendelsohn, M., Axel, R., 2004. Odorant receptors on axon termini in the brain. Science 304, 1468 .

Belluscio, L., Gold, G.H., Nemes, A., Axel, R., 1998. Mice deficient in $G_{\text {olf }}$ are anosmic. Neuron 20,69-81.

Bozza, T., Feinstein, P., Zheng, C., Mombaerts, P., 2002. Odorant receptor expression defines functional units in the mouse olfactory system. J. Neurosci. 22, 3033-3043.

Buck, L., Axel, R., 1991. A novel multigene family may encode odorant receptors: a molecular basis for odor recognition. Cell 65, 175-187.

Bush, C.F., Hall, R.A., 2008. Olfactory receptor trafficking to the plasma membrane. Cell. Mol. Life Sci. 65, 2289-2295.

Bush, C.F., Jones, S.V., Lyle, A.N., Minneman, K.P., Ressler, K.J., Hall, R.A., 2007. Specificity of olfactory receptor interactions with other G-protein coupled receptors. J. Biol. Chem. 282, 19042-19051.

Chruscinski, A.J., Rohrer, D.K., Schauble, E., Desai, K.H., Bernstein, D., Kobilka, B.K., 1999. Targeted disruption of the $\beta 2$ adrenergic receptor gene. J. Biol. Chem. 274, 16694-16700.

Ennis, M., Zhou, F.M., Ciombor, K.J., Aroniadou-Anderjaska, V., Hayar, A., Borrelli, E. Zimmer, L.A., Margolis, F., Shipley, M.T., 2001. Dopamine D2 receptor-mediated presynaptic inhibition of olfactory nerve terminals. J. Neurophysiol. 86, 2986-2997.

Feinstein, P., Mombaerts, P., 2004. A contextual model for axonal sorting into glomeruli in the mouse olfactory system. Cell 117, 817-831.
Feinstein, P., Bozza, T., Rodriguez, I., Vassalli, A., Mombaerts, P., 2004. Axon guidance of mouse olfactory sensory neurons by odorant receptors and the $\beta 2$ adrenergic receptor. Cell 117, 833-846.

Grosmaitre, X., Vassalli, A., Mombaerts, P., Shepherd, G.M., Ma, M., 2006. Odorant responses of olfactory sensory neurons expressing the odorant receptor MOR23: a patch clamp analysis in gene-targeted mice. Proc. Natl. Acad. Sci. U. S. A. 103, 1970-1975.

Grosmaitre, X., Santarelli, L.C., Tan, J., Luo, M., Ma, M., 2007. Dual functions of mammalian olfactory sensory neurons as odor detectors and mechanical sensors. Nat. Neurosci. $10,348-354$.

Grosmaitre, X., Fuss, S.H., Lee, A.C., Adipietro, K.A., Matsunami, H., Mombaerts, P., Ma, M., 2009. SR1, a mouse odorant receptor with an unusually broad response profile. J. Neurosci. 29, 14545-14552.

Hague, C., Uberti, M.A., Chan, Z., Bush, C.F., Jones, S.V., Ressler, K.J., Hall, R.A., Minneman, K.P., 2004. Olfactory receptor surface expression is driven by association with the B2-adrenergic receptor. Proc. Natl. Acad. Sci. U. S. A. 101, 13672-13676.

Hegg, C.C., Lucero, M.T., 2004. Dopamine reduces odor- and elevated- $\mathrm{K}^{+}$-induced calcium responses in mouse olfactory receptor neurons in situ. J. Neurophysiol. 91, 1492-1499.

Ishii, T., Mombaerts, P., 2008. Expression of nonclassical class I major histocompatibility genes defines a tripartite organization of the mouse vomeronasal system. J. Neurosci. $28,2332-2341$.

Ishii, T., Omura, M., Mombaerts, P., 2004. Protocols for two- and three-color fluorescent RNA in situ hybridization of the main and accessory olfactory epithelia in mouse. J. Neurocytol. 33, 657-669.

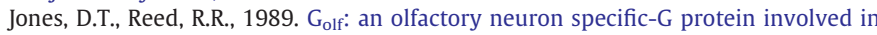
odorant signal transduction. Science 22, 790-795.

Kawai, F., Kurahasahi, T., Kaneko, A., 1999. Adrenaline enhances odorant contrast by modulating signal encoding in olfactory receptor cells. Nat. Neurosci. 2, 133-138.

Khan, M., Vaes, E., Mombaerts, P., 2011. Regulation of the probability of mouse odorant receptor gene choice. Cell 147, 907-921.

Khan, M., Vaes, E., Mombaerts, P., 2013. Temporal patterns of odorant receptor gene expression in adult and aged mice. Mol. Cell. Neurosci. http://dx.doi.org/10.1016/ j.mcn.2013.08.001.

Kobilka, B., 2013. The structural basis of G-protein coupled receptor signaling (Nobel lecture). Angew. Chem. Int. Ed. Engl. 52, 6380-6388.

Koster, N.L., Norman, A.B., Richtand, N.M., Nickell, W.T., Puche, A.C., Pixley, S.K., Shipley, M.T., 1999. Olfactory receptor neurons express D2 dopamine receptors. J. Comp. Neurol. 411, 666-673.

Lam, R., Mombaerts, P., 2013. Odorant responsiveness of embryonic mouse olfactory sensory neurons expressing the odorant receptors S1 or MOR23. Eur. J. Neurosci. 38, 2210-2217.

Lee, A.C., He, J., Ma, M., 2011. Olfactory marker protein is critical for functional maturation of olfactory sensory neurons and development of mother preference. J. Neurosci. 31 2974-2982.

Lefkowitz, R.J., 2013. A brief history of G-protein coupled receptors (Nobel lecture). Angew. Chem. Int. Ed. Engl. 52, 6380-6388.

Li, Y.R., Matsunami, H., 2011. Activation state of the M3 muscarinic acetylcholine receptor modulates mammalian odorant receptor signaling. Sci. Signal. 4, ra1.

Liu, H.Y., Wenzel-Seifert, K., Seifert, R., 2001. The olfactory G protein $G_{\alpha o l f}$ possesses a lower GDP-affinity and deactivates more rapidly than $\mathrm{G}_{\text {s } \alpha \text { short }}$ : consequences for receptor-coupling and adenylyl cyclase activation. J. Neurochem. 78, 325-338.

Ma, M., Chen, W.R., Shepherd, G.M., 1999. Electrophysiological characterization of rat and mouse olfactory receptor neurons from an intact epithelial preparation. J. Neurosci. Methods 92, 31-40.

Mombaerts, P., Wang, F., Dulac, C., Chao, S.K., Nemes, A., Mendelsohn, M., Edmondson, J. Axel, R., 1996. Visualizing an olfactory sensory map. Cell 87, 675-686.

Nakashima, A., Takeuchi, H., Imai, T., Saito, H., Kiyonari, H., Abe, T., Chen, M., Weinstein, L.S., Yu, C.R., Storm, D.R., et al., 2013. Agonist-independent GPCR activity regulates anterior-posterior targeting of olfactory sensory neurons. Cell 154, 1314-1325.

Nguyen, M.Q., Zhou, Z., Marks, C.A., Ryba, N.J.P., Belluscio, L., 2007. Prominent roles for odorant receptor coding sequences in allelic exclusion. Cell 131, 1009-1017.

Okada, Y., Miyamoto, T., Toda, K., 2003. Dopamine modulates a voltage-gated calcium channel in rat olfactory receptor neurons. Brain Res. 968, 248-255.

Rodriguez, I., Feinstein, P., Mombaerts, P., 1999. Variable patterns of axonal projections of sensory neurons in the mouse vomeronasal system. Cell 97, 199-208.

Rohrer, D.K., Desai, K.H., Jasper, J.R., Stevens, M.E., Regula, D.P., Barsh, G.S., Bernstein, D. Kobilka, B., 1996. Targeted disruption of the mouse $\beta 1$-adrenergic receptor gene: developmental and cardiovascular effects. Proc. Natl. Acad. Sci. U. S. A. 93 7375-7380.

Sammeta, N., Yu, T.T., Bose, S.C., McClintock, T.S., 2007. Mouse olfactory sensory neurons express 10,000 genes. J. Comp. Neurol. 502, 1138-1156.

Strotmann, J., Levai, O., Fleischer, J., Schwarzenbacher, K., Breer, H., 2004. Olfactory receptor proteins in axonal processes of chemosensory neurons. J. Neurosci. 24, 7754-7761.

Vassalli, A., Rothman, A., Feinstein, P., Zapotocky, M., Mombaerts, P., 2002. Minigenes impart odorant receptor-specific axon guidance in the OB. Neuron 35, 681-696. 